\title{
ILCEA
}

Revue de l'Institut des langues et cultures

d'Europe, Amérique, Afrique, Asie et Australie

9| 2007

L'implicite et les écrits de l'entreprise

\section{Lexical Analysis of Implicit Promotional Devices in Bank Annual Reports}

Donatella Malavasi

\section{(Q) OpenEdition \\ Journals}

Electronic version

URL: http://journals.openedition.org/ilcea/724

DOI: 10.4000/ilcea.724

ISSN: 2101-0609

\section{Publisher}

UGA Éditions/Université Grenoble Alpes

\section{Printed version}

Date of publication: 15 December 2007

Number of pages: 171-184

ISBN: 978-2-84310-104-5

ISSN: $1639-6073$

Electronic reference

Donatella Malavasi, « Lexical Analysis of Implicit Promotional Devices in Bank Annual Reports », ILCEA [Online], 9 | 2007, Online since 09 June 2010, connection on 02 May 2019. URL : http:// journals.openedition.org/ilcea/724; DOI : 10.4000/ilcea.724

() ILCEA 


\title{
Lexical Analysis of Implicit Promotional Devices in Bank Annual Reports
}

\author{
Donatella MALAVASI \\ University of Modena and Reggio Emilia (Italy)
}

\begin{abstract}
Among the many diverse business discourses, this article focuses on a particular financial genre, Bank Annual Reports (ARs). The main assumption underlying this study concerns the overlapping nature of these disclosures which overtly fulfil informative goals but covertly and concomitantly fulfil promotional ones as well. Starting with a general presentation of the distinctive features of Bank ARs, the article will pinpoint the lexical and discursive devices utilized to highlight the institution's specificities, its successful performance and ethical values. Particular attention will be paid to the implicit and unexpressed evaluative resources deployed by AR writers to discreetly but efficiently promote a particular financial group, enticing the audience into taking advantage of services advertised through explicit but also invoked and indirect references.
\end{abstract}

\section{RÉSUMÉ}

Parmi les nombreux et diversifiés discours émanant du monde des affaires, l'objet d'étude de cet article est un genre financier particulier, celui du rapport annuel publié par les banques. La principale hypothèse qui sous-tend cette analyse concerne la nature double de ce discours qui remplit à la fois un objectif informatif ouvertement affiché en même temps qu'un objectif promotionnel plus discret. Après une présentation générale des caractéristiques définitoires du genre, l'article analyse les stratégies lexicales et discursives mises en œuvre pour mettre en valeur les spécificités de l'institution, sa performance et ses valeurs éthiques. Une attention toute particulière est accordée à l'analyse des ressources évaluatives implicites exploitées par les rédacteurs des rapports annuels pour promouvoir de manière discrète mais efficace tel ou tel groupe financier, incitant ainsi le lecteur à profiter des services proposés à travers des références explicites mais aussi évoquées et implicites.

Key words

Bank Annual Reports, Evaluative Lexis, Implicitness, Persuasion.

\section{Mots clés}

Rapports annuels des banques, lexique évaluatif, l'implicite, la persuasion. 


\section{Annual Reports}

In the wide field of business communication studies, corporate Annual Reports (ARs) have been categorised as records published every year by publicly held corporations that detail their financial standing. The report, which is distributed to shareholders, investors, employees and analysts, describes the company's operations, its balance sheet, future prospects and other relevant information (Wainwright, 1984; Moore \& Hesp, 1985; Ellis \& Johnson, 1994; Jay, 1995).

Annual reports have been widely accepted to represent financial investor relations which provide investors with objective performancerelated information (Marston \& Straker, 2001; Watson, 2005). However, in addition to their informative goals, these reports also attempt to create strong and trust-based relations with their audience, to establish a favourable image ${ }^{1}$ and promote themselves and their services (Dolphin, 2004; Tosun, 2004; Malavasi, 2005). Even if still sometimes disputed, the existence of this blend of information and persuasion in reports is generally unanimously agreed upon (Wainwright, 1984; Moore \& Hesp, 1985; Burrough, 1986; Anderson \& Imperia, 1992; Kohut \& Segars, 1992; Rezaee \& Porter, 1993; Yuthas, Rogers \& Dillard, 2002; Hynes \& Bexley, 2003). A particular instance of ARs, namely Bank ARs, has been recognized (Malavasi, 2006) as possessing three overlapping purposes: apart from their crucial information disclosing function, the promotional nature of these financial instances permeates the texts through a great amount of persuasive information conveyed by $A R$ writers. The numerous descriptions of banks and their activities contribute to the creation of a reliable corporate identity ${ }^{2}$, endeavour to convince readers of the bank's intrinsic qualities and, naturally, promote their financial products. Finally, ARs attempt also to strengthen the bank's own corporate culture ${ }^{3}$ by spreading a commendable value-system. This triple function of AR discourse - disclosure of information, laudatory self-appraisal and consolidation of a strong corporate culture or creed - are the reflection of the institution's desire to

1. Quoting Topalian (2003:1120), "[c]orporate image is the sum of impressions and expectations of an organisation built up in the mind of its stakeholders and public (British Standards Institution, 1995)".

2. The corporate identity of a firm can be defined as "the articulation of what an organization is, what it stands for, what it does and how it goes about its business (especially the way it relates to its stakeholders and the environment) (Britsh Standards Institution, 1995)" (Topalian, 2003:1119).

3. Corporate culture includes "myths, rituals, and stories articulated and managed in order to integrate the organization's members around one shared reality." (Christensen, 2002:164). 
'promote' its name, market itself, construct a positive institutional identity, and create goodwill with the public.

From a more content-based viewpoint ARs convey financial data which tend to be generally collected and organised in more or less detailed reports. However, ARs are additionally constituted of narrative texts which, "intended to supplement the report's required financial information, include the Management's Discussion and Analysis (MD\&A) and the executive's letter" (David, 2001, cited in Watson, 2005:3). These remarks seem to confirm Ingram \& Frazier's (1983) and Kohut \& Segars's (1992) distinction between two different types of information disclosure: non-financial, non-quantitative, narrative and discretionary disclosures (i.e. not constrained by and not necessarily consistent with financial statements) as opposed to financial, numerical and nondiscretionary reports (i.e. necessarily consistent with the firm's financial performance and related data).

Although these documents are overtly and prominently informative, their latent promotional nature can be perceived throughout the texts and more patently in their narrative and discretionary parts (see the section "materials and methods"). In an attempt to shed some light on the hidden and less transparent promotional nature of bank reports, emphasis will be laid on the hub around which the persuasive force of the disclosures revolves: the lexis selected by $\mathrm{AR}$ writers to express attitudes towards the banks represented (i.e. markers of subjectivity), give a positive evaluation of the financial group (i.e. evaluative lexis), and present their viewpoints in a matter-of-fact way (i.e. markers of implicitness).

\section{Preliminaries: Subjectivity, Evaluation and Implicitness}

Lyons (1977) posited that subjectivity - the speaker's choice of one word rather than another - reveals his/her attitudes towards what s/he is talking about and can thus influence, please or antagonize the listener.

More specifically, assuming that «[l']activité langagière, dans sa totalité, est subjective» (2002:77), Kerbrat-Orecchioni proposes «une linguistique de l'énonciation» centred on the examination of «[...] les traces linguistiques de la présence du locuteur au sein de son énoncé, les lieux d'inscription et les modalités d'existence de ce qu'avec Benveniste nous appellerons "la subjectivité dans le langage"» (ibid.: 36). In her categorisation of the «[...] opérateurs de subjectivité particulièrement voyants et efficaces» (ibid.: 93), she mentions «les substantifs et les adjectifs affectifs ${ }^{4}$, les substantifs et les adjectifs

4. Les substantifs et les adjectifs affectifs «énoncent [...] une réaction émotionnelle du sujet parlant en face de cet object. [...] ils impliquent un engagement affectif de l'énonciateur [...]» (Kerbrat-Orecchioni, 2000: 95). 
évaluatifs non axiologiques ${ }^{5}$ vs. axiologiques ${ }^{6}$, les verbes occasionnellement et intrinsèquement subjectifs $s^{7}$ » (ibid.: 82-132).

Among the diversified «lieux langagiers où s'inscrit plus ou moins explicitement le sujet d'énonciation» (Kerbrat-Orecchioni, 2002:163), the lexis expressing evaluation can be identified as a hyponymy of the superordinate represented by subjectivity. Specifically, evaluative lexical items represent the ways in which writers enter the text and express their attitudes towards the entity they are talking about (Thompson \& Hunston), 2000:5). Evaluative resources are deployed to transmit, either explicitly or implicitly, through texts, "what counts as good or bad, what should or should not happen, what counts as true or untrue" (Thompson \& Hunston, 2000:8).

The Value dimension of evaluation which operates along a 'goodbad' scale (Hunston, 1993:62-65; Thompson \& Hunston, 2000:22-26), or "le trait axiologique de (dé)valorisation des unités lexicales" (KerbratOrecchioni, 2002), is sometimes immediately perceivable in propositional contents and denotatively positive meanings, but it can also be inferred from those lexical items, which imply and connotatively suggest admirable patterns or arouse readers' positive feelings ('inscribed' vs 'evoked' / 'invoked' evaluation, see the appraisal theory proposed by Martin, 2000 and White, 2002). In Kerbrat-Orecchioni's terms (2002:103), «les évaluatifs axiologiques » can be subdivided into «[...] ceux qui sont marqués de façon relativement stable d'un trait de (dé)valorisation attaché au sémème de l'unité, et ceux qui, dans tel idiolecte ou tel contexte particuliers, peuvent occasionnellement se charger d'une connotation axiologique».

The lexical means, which do not directly describe the 'goodness' of an entity, such as a bank, but acquire a pragmatically positive attitudinal meaning, a 'good' semantic prosody ${ }^{8}$ (see Louw, 1993; Partington, 2004; Sinclair, 1991, 2003 and 2004), discourse prosody ${ }^{9}$ (Stubbs, 2001), or polarity (Channell, 2000), represent one of the main concerns of the

5. Les substantifs et les adjectifs évaluatifs non axiologiques "[...] impliquent une évaluation qualitative ou quantitative [...]" (ibid. pp. 96-97)

6. Les substantifs et les adjectifs évaluatifs axiologiques "portent [...] un jugement de valeur, positif ou négatif" (ibid. p. 102).

7. The two categories of verbs display a different "source de l'évaluation, c'est l'agent $d u$ procès (verbes occasionnellement subjectifs) vs le sujet d'énonciation (verbes intrinsèquement subjectifs)" (ibid. p. 129). Furthermore, another distinction is made between the verbs which express «une évaluation de type bon/mauvais» and those which express «une évaluation de type vrailfaux $\gg$ (ibid. p. 114).

8. As suggested by Sinclair (2003:117), semantic prosody refers to the extra emotive or attitudinal meaning carried by a word in a particular context.

9. Stubbs uses the expression 'discourse prosody' arguing that, since prosodies express speakers' attitudes, "semantic" would be misleading as it refers to aspects of meaning independent of speakers or writers. 
realm of implicitness (as well as presuppositions, implicatures, etc., for an overview of these notions, see Brown and Yule, 1983; Levinson, 1983; Bertuccelli Papi, 2000; Ducrot, 2003).

The dichotomy between explicitness and implicitness is to be interpreted as corresponding to «formules subjectives qui s'avouent comme telles» and «formules subjectives qui tentent de se faire passer pour objectives», respectively (Kerbrat-Orecchioni, 2002, p. 167). In an analogous vein, Ducrot (2003, p. 6) defines the notion of implicitness as «des modes d'expression [...], qui permettent de laisser entendre [des informations que le locuteur n'a pas le droit de donner aux allocutaires] sans encourir la responsabilité d'avoir dit». In particular, implicitness is intended, according to Bertuccelli Papi (2000), as a cover term for phenomena such as the inexplicit $^{10}$, the implicated ${ }^{11}$ and the subplicit. In line with the analytic approach adopted in the article, subplicitness deserves more careful consideration, as it "comprehends all those reverberations of meaning (be they intentional or not) which are triggered not so much by the conceptual representation of what is said as by the attitude(s) explicitly or inexplicitly attached to it." (Bertuccelli Papi, 2000:21-22). An utterance, indeed, is the addresser's expression of content and thought and also, simultaneously, attitude, which can be either explicitly made manifest but is more often made indirectly perceivable and inferable by the addressee. Attitudes are commonly "[...] conveyed by what is not said, or better, by the choice of the speaker not to say something explicitly, to leave something inexplicit or give it as understood." (Bertuccelli Papi, 2000:241).

Thus, embracing the assumption that for maximal success, persuasion needs to be implicit (Halmari \& Virtanen, 2005), the study aims to highlight some lexical and discursive patterns which implicitly express evaluation and its Value dimension. Particular attention will be placed on those strategies which « $[. .$.$] permettent au locuteur de susciter certaines opi-$ nions chez le destinataire sans prendre le risque de les formuler lui-même; elles permettent donc de faire croire sans avoir dit». (Ducrot, 2003:15).

10. Bertuccelli Papi (2000:21) puts forward that "[t]he inexplicit [is] linguistically anchored to what is said by an utterance-type, depends on grammar and conventional knowledge as expressed in the language, and makes use of immediately perceivable sources of information, such as the cotext or the perceptual context."

11. The implicated is defined by Bertuccelli Papi (2000, p. 21) as "includ[ing] implicit meanings generated by the search for relevance of an utterance-token, and assum[ing] intentionality among the premises for the inferential reasoning." 


\section{Materials and Methods}

The analysis of the subtly persuasive vocabulary, which the promotional nature of ARs hinges on, focuses on some discretionary and narrative sections, viz. the Chairman's Statement (ch), the Chief Executive's Report (ce), the Bank and Business Description (b), and the Corporate Governance Description (cg). These portions of texts have been selected since, quoting McConnell, Haslem \& Gibson (1986:66), "[h]ere, management is free to provide whatever assessments of [present and] prospective firm performance it deems important. These assessments are not immediately verifiable."

In particular, data for the analysis correspond to 142 bank AR narrative and descriptive sections (in total, approximately 473,000 words) drawn from a larger reference corpus, which includes 47 reports (in total, about 3 million tokens) published in English on the Web between 1995 and 2002 by the following major European Banks: Hong Kong and Shanghai Banking Corporation Holdings (hsbc), Royal Bank of Scotland (rbs), Barclays Bank plc (bar), Lloyds TSB Group (llo) in the UK; Crédit Lyonnais (cl) in France; Deutsche Bank (db) in Germany; Banca Intesa in Italy (int), Credit Suisse (cs) and the Union Bank of Switzerland (ubs) in Switzerland.

The creation of the smaller corpus represents the starting point of the study which sets out to accomplish, by means of corpus linguistic tools, a quantitative and qualitative investigation of evaluative lexis. The overall examination consists of a manual identification of the evaluatively positive lexis (adjectives, verbs and nouns) which co-occurs with some search words (i.e. group(s), bank(s) as well as their proper name, business(es) and service(s)). More in detail, in the process of manual skimming of all the concordances of the selected nodes, prominence has been given to those attitudinal tools and other more discursive elements which invoke the bank's outstanding characteristics, contribute to the latent fulfilment of persuasive goals, and inspire a wealth of consensus amongst readers regarding the bank.

\section{Results}

The numerical and quantitative analysis carried out by using WordSmith wordlisting and concordancing tools (Scott, 1998) reveals that evaluative lexis tends to accompany, even if not uniformly, all the chosen search words, group(s), bank(s), business(es) and services(s), (Malavasi, 2005). 
More in detail, the approbatory adjectives, verbs and nouns recognized as evaluative or axiologiques (Kerbrat-Orecchioni, 2002) express, in fact exclusively, 'what counts as good', such as pre-eminent, succeed, and profitability in the following sentences (my emphasis):

1. Deutsche Bank aspires to be a leading global provider of integrated financial solutions for demanding clients and the pre-eminent bank in Germany generating exceptional value for its shareholders and people. $(\mathrm{dbcg} 02)$

2. Even in the challenging second half of 2000, the Group succeeded in sustaining its strong performance of the first six months, and net operating profit for the year rose by a total of $35 \%$ to CHF 7.2 billion. (cschce00)

3. 2001 was another year of substantial improvement in the strength and profitability of our Group. (rbsch01)

The highly evaluative expressions appearing in the above excerpts highlight those lexical means which explicitly convey a positive meaning irrespective of the entity they refer to or the context/co-text in which they are used. Explicitly or denotatively evaluative meanings appear to be inscribed in a number of adjectives (best, prime, first-rate, prestigious, premier, first-class, world-class, top, excellent, outstanding, superb, successful, etc.), verbs (outperform, improve, streamline, reach, meet, top, attain, gain, etc.), and nouns (excellence, soundness, sophistication, innovation, importance, achievement, improvement, efficiency, etc.).

Concurrently, however, laudatory meanings are more frequently expressed in an indirect and more implicit way. As far as the financial world of banks is concerned, "[t]his second class of evaluative means includes the lexical patterns which, even apparently neutral, assume a positive connotation because of either their surrounding favourable cotext or the positive value they recall." (Malavasi, 2005:7).

Some of the adjectives which embed an appeal to the financial group's positive features or creed are global (ex. 4), big/bigger/biggest, integrated, focused, international, new, client-oriented, customer-related....

4. As a global banking group, we consider ourselves well placed to provide products and services to those personal customers who require delivery across the world. (hsbcce99)

The 'goodness' of these attributes is evoked by their surrounding lexical environment which draws attention to the bank's importance, competitiveness, international role, innovation capacity, tradition, customer focus, etc. In particular, persuasive and promotional goals are implicitly fulfilled by means of a number of evaluative attributes which owe their positive aura to the fact that they imply a bank's more profitable and convenient advantages in comparison with competitors. These attributes (in their comparative of increase or superlative forms) are employed to stress more or less overtly a bank's higher level of 'goodness' in comparison with other financial institutions. The terms of comparison - i.e. other banks and their businesses - enter the text either implicitly (in 
unqualified comparative forms, see ex. 5) or explicitly (in qualified superlative forms, see ex. 6).

5. We are expanding into new geographies and new customer segments, and will be launching more personalised products and services. (barb01)

6. For example, we were able to enhance our strong position in Europe - we are already the biggest foreign bank in Italy and Spain - through the acquisition of Crédit Lyonnais Belgium, through the strategic alliance with EFG Eurobank in Greece, and through our cooperation with the Spanish Post Office. (dbch98)

Apart from adjectives, subplicit attitudinal verbs carry a heavy weight in the realization of connotatively evaluative meanings. Indirectly laudatory descriptions are linguistically implemented by means of a host of verbs which, through their positive semantic prosody, implicate references to thriving performance and profitable advantages resulting from responsibly decided courses of action (e.g. offer, maintain, undertake, provide, establish, perform, deliver, launch, experience, operate in ex. 7).

7. The HSBC Group has always operated to the highest standards of conduct and, as a matter of routine, takes account of reputational risks to its business. (hsbccg02)

Similarly to action-oriented verbs, involvement-related verbs pervade Annual Reports. In particular, verbal instances such as focus, intend, support, encourage (ex. 8), commit, pursue, believe, seek, aim, foster, aspire, desire, etc., assume a value-laden shade of meaning. This can be explained in terms of the co-occurrence of such verbs with the linguistic expression of the bank's commendable guiding principles and strong commitment to achieve gains for its different stakeholders:

8. Staff involvement. The Group encourages employee involvement through a process of communication and consultation. (rbscg01)

More in detail, a number of such verbs are used to express the bank's future performance, projects and goals. This pattern, which Rezaee \& Porter (1993) define as a strategy aiming at persuading AR readers, is linguistically analysed by Martin (2000, p. 150) in terms of 'irrealis' evaluation. In his definition of the concept, Martin suggests that 'irrealis' evaluation involves feelings which relate to future events, whereas 'realis' evaluation concerns existing states.

In bank ARs, the contrast between 'realis' (ex. 9) and 'irrealis' (ex. 10) evaluative constructions is testified to by the following examples:

9. Through these undertakings, the bank provides a comprehensive range of banking and related financial services. (hsbccg01)

10. The Create offer will be underpinned by access to the comprehensive broking services of Goldman Sachs PrimeAccess ${ }^{\mathrm{TM}}$. This service will provide clients with customised proprietary research from Goldman Sachs, international equity dealing and market making, custody and settlement, and access to selected equity capital market offerings managed by Goldman Sachs. (lloce00) 
The action described in sentence 9 corresponds to a matter of fact, whereas the affairs sketched out in example 10 are not existing but future plans of the bank. The lexis used to express 'irrealis' evaluation is a profitable contribution to the positive but veiled suggestion that banks meticulously plan their actions to attain positive results and meet their clients' needs. On a par with adjectives and verbs, a wide range of apparently neutral nominal forms such as internationality, spread, expansion, growth, creation and development (instance 11), performance, ability, array, range, capability, contribution, diversity, diversification, etc., assume a positive meaning thanks to the surrounding favourable co-text (e.g. the right products [...] are achieved).

11. It is through continued investment in customer information systems, and the wealth of customer data that these provide, that the creation and development of the right products and services are achieved. (barb00)

Besides positive lexis - either denotatively or connotatively evaluative negative lexical constructions also constitute a strategy which contributes to the bank's hidden achievement of persuasive goals.

Negative elements rarely precede the four key terms under investigation. The only 'bad' descriptions identified in the ARs under study represent the collapsing financial scenario in which the groups operate rather than directly involve the bank and the actions it undertakes.

Such patterns are used by banks to present bad news and facts as being caused by more general circumstances for which they are not thought to be responsible (Thomas, 1997). In particular, as evidenced by the following extracts, when banks obtain positive performance, it is because of their concerted far-sighted decisions (ex. 12); when results are poor, it is due to the challenging financial panorama beyond their control (ex. 13):

12. We achieved a record level of product sales, and market share gains in many of our core markets. (lloce00)

13. The uncertain context - especially as concerns the general strategies to be adopted to invert the negative trends - is still the greatest concern and binders growth especially in the Western area. This situation obviously also affected Banca Intesa: 2002 was not a brilliant year. (intce02)

Negative results are generally presented as a consequence of the uncertain economic background: it is because of negative financial variables that the bank's performance is not brilliant. Non-human agents become the subjects of sentences which report on negative situations (e.g. business in sentence 14), whereas human agents, such as the bank's name, and the institutional we-form are used to detail positive performance (cf. example 12 above). 
14. Our investment banking business weakened in the second half of 1997; however, it remained profitable against a backdrop of significant changes and volatile earnings within the industry. (hsbcch97)

When negative financial results (usually caused by outside factors) are described, the mediocrity of these results is mitigated. This rhetorical effect is achieved by means of concessive constructions which enable the financial scenario to be presented as uncertain and weak, and the bank as making progress despite the hindering context (cf. ex. 15).

15. The International Private Banking business, which is based in Geneva where Crédit Lyonnais has just celebrated its 125 th anniversary, continued to enjoy sustained growth despite a difficult stock market environment. (clb01)

The formulation of concessive constructions, introduced by the preposition despite, is common in ARs. In line with Garzone's observations (2005:135-136), these devices function as a tool employed to "enhanc[e] the positive performance of the company by underlining its unexpectedness when seen against the background of unfavourable underlying economic conditions." Consequently, by means of such strategic elements, negative trends are underplayed and almost neutralized, allowing the bank's positive financial standing to emerge more strongly.

\section{Discussion and Conclusions}

In contrast with their generally recognized objective and informative nature, bank annual reports represent promotional disclosure as well, characterised (especially in their narrative sections) by the widespread presence of emotive, subjective and evaluative language.

However, the lexis used in ARs to present banks and their services in a good light tends not to be explicitly marked. Evaluation is indeed in itself very often implicit, in the sense that the writer's viewpoint on or feelings about the entity that s/he is talking about is barely perceptible and very often to be inferred (see Hunston \& Thompson, 2000). In addition to its implicit nature, evaluation has been demonstrated to be linguistically realised by means of strings of words which cumulatively recall the outstanding features and values of financial institutions. In particular, apparently neutral words are imbued with a positive pragmatic meaning or semantic prosody by the general context in which they appear and the surrounding favourable co-text.

The use of such concealed evaluative strategies is motivated by different reasons. First of all, the recourse to strings of words (instead of single words) as repositories of hidden positive attitudes allows AR writers to create not an explicit and circumscribed but covertly pervasive and persistent aura of 'goodness' and probity around the bank. 
Moreover, the preponderance of implicit evaluation is to be explained in terms of the advantages $\mathrm{AR}$ writers obtain by drawing on the indirect $v s$. direct way of communicating meanings. In particular, "[...] by being indirect the speaker can authorize the inference that he is tactful, nonimposing, non-coercive, while avoiding responsibility for the potentially face-damaging interpretations of his acts." (Bertuccelli Papi, 2000: 79). Accordingly, bank managers, who are responsible for drafting the annual report, aim to be recognized by the general audience of investors and analysts not as manipulative and deceitful financial experts, but rather as careful and thoughtful consultants. Indeed, the primary goal they want to make manifest is not to manipulate readers but to provide investors with precise and truthful financial information, backed by numerical data, which concerns not only successful and profitable performance but also poor results. However, it cannot be denied that annual reports attempt to convince the audience that 'here's why our financial institution is a worthwhile investment'. The promotional nature of financial disclosures can be traced back to that process labelled by Bhatia (2005: 213-225) as "promotionalisation of discourse". According to this phenomenon, a growing number of discursive instances, in addition to ARs, have appropriated promotional and marketing elements. A crucial role in the 'advertising' function of ARs is played by the lexical items. Emotionally charged and audience-appealing vocabulary permeates the narrative sections of ARs serving to appraise the bank's good points, foster addressee confidence and mould their opinion in favour of the bank.

In accordance with the existing literature (Halmari \& Virtanen, 2005), what the study ventures to demonstrate is that the use of implicitly, subplicitly and invokedly evaluative or subjective lexis corresponds to one of the most effective and advantageous ways of captivating the audience not blatantly, but 'sensitively', 'tactfully' and 'objectively'. The recourse to connotatively positive lexis and to implicitness contributes to the AR attainment of persuasive goals. Persuasion has been widely accepted to reach effectiveness when it takes place in an implicit and pragmatic manner: in Östman's words (2005:199), “[...] the more you try to overtly persuade somebody into doing something, the less likely this somebody will be to actually do the thing." This subtlety in AR promotional nature is realised by means of indirectly evaluative lexical items which create in the mind of the addressee positive emotions, judgements and conviction that 'it would be profitable to benefit from that bank's offer'. In conclusion, in keeping with Aristotle, "[...] persuasion may come through the hearers, when the speech stirs their emotions. Our judgements when we are pleased and friendly are not the same as when we are pained and hostile." (Aristotle [1984]:25, cited in Virtanen \& Halmari, 2005:7). Thus, whenever an AR makes its reader pleased with 
the bank, the disclosures will have succeeded in their mission, i.e. effortlessly and successfully enticing the target audience into buying the bank's products.

\section{Bibliography}

Anderson C.J. \& G. Imperia, «The Corporate Annual Report: A Photo Analysis of Male and Female Portrayals», The Fournal of Business Communication, $n^{\circ}$ 29/2, 1992, Spring, pp. 113-128.

Bertuccelli Papi M., Implicitness in Text and Discourse, Pisa, Edizioni ETS, 2000.

Bhatia V.K., «Generic patterns in promotional discourse», Persuasion Across Genres: a Linguistic Approach, H. Halmari \& T. Virtanen (eds.), Amsterdam/ Philadelphia, John Benjamins, 2005, pp. 213-225.

Brown G. \& G. Yule, Discourse Analysis, Cambridge, Cambridge University Press, 1983.

Burrough B., «Here is our Report on a Report about Corporate Annual Reports», Wall Street Fournal, New York, 1986, Oct. 23, p. 35.

Channell J., «Corpus-based analysis of evaluative lexis», Evaluation in Text. Authorial Stance and the Construction of Discourse, S. Hunston \& G. Thompson (eds.), Oxford, Oxford University Press, 2000, pp. 38-55.

Christensen L.T., «Corporate Communication: the challenge of transparency», Corporate Communications: An International fournal, n 7/3, 2002, pp. 162-168.

Dolphin R. R., «The strategic role of investor relations», Corporate Communications: An International Fournal, nº 9/1, 2004, pp. 25-42.

Ducrot O., Dire et ne pas dire. Principes de sémantique linguistique, Paris, Hermann, Éditeurs des Sciences et des Arts, 2003.

Ellis M. \& C. Johnson, Teaching Business English. Oxford, Oxford University Press, 1994.

Garzone G., «Pragmatic and discoursal features of annual executive letters: observations on the rhetorical and evaluative function of concessive constructions», Cross-Cultural Encounters: Linguistic Perspectives, M. Bondi \& N. Maxwell (eds.), Rome, Officina Edizioni, 2005, pp. 130-143.

Halmari H. \& T. Virtanen (eds.), Persuasion Across Genres: a Linguistic Approach, Amsterdam/Philadelphia, John Benjamins, 2005.

Hunston S., «Evaluation and ideology in scientific writing», Register Analysis: Theory and Practice, M. Ghadessy (ed.), London/New York, Pinter Publishers, 1993, pp. 57-73.

Hynes G.E. \& J.B. Bexley, «Understandability of Banks' Annual Reports», Proceedings of the 2003 ABC Annual Convention, 2003.

Ingram R.W. \& K.B. Frazier, «Narrative disclosures in Annual Reports», Fournal of Business Research, $\mathrm{n}^{\circ} 11,1983$, pp. 49-60.

Jay R., How to write proposals and reports that get results, London, Pitman Publishing, 1995.

Kerbrat-Orecchioni C., L'énonciation, Paris, Armand Colin, 2002.

Kohut G.F. \& A.H. Segars, «The President's Letter to Stockholders: An Examination of Corporate Communication Strategy», The fournal of Business Communication, $\mathrm{n}^{\circ}$ 29/1, 1992, Winter, pp. 7-21.

Levinson S. C., Pragmatics, Cambridge, Cambridge University Press, 1983. 
Louw B., «Irony in the Text or Insincerity in the Writer? The Diagnostic Potential of Semantic Prosodies», Text and Technology: in Honour of fohn Sinclair, M. Baker, G. Francis \& E. Tognini-Bonelli (eds.), Amsterdam/Philadelphia, John Benjamins, 1993, pp. 157-176.

Lyons J., Semantics, Cambridge, Cambridge University Press, 1977.

Malavasi, D., Banks' Annual Reports: An Analysis of the Linguistic Means used to Express Evaluation, 2005.

http://www.businesscommunication.org/conventions/Proceedings/2005/ABCEuro pe2005Proceedings.html

Malavasi D., Banks' Annual Reports: a multi-angled linguistic analysis of evaluation. Unpublished Ph.D. Dissertation. 2006.

Marston C. \& M. Straker, «Investor relations: a European survey», Corporate Communications: An International fournal, n 6/2, 2001, pp. 82-93.

Martin J. R., «Beyond Exchange: APPRAISAL Systems in English», Evaluation in Text. Authorial Stance and the Construction of Discourse, S. Hunston \& G. Thompson (eds.), Oxford, Oxford University Press, 2000, pp. 142-175.

McConnell D., Haslem J. A. \& V. R. Gibson, «The President's Letter to Stockholders: A New Look», Financial Analysts fournal, 1986, SeptemberOctober, pp. 66-70.

Moore N. \& M. Hesp, The Basics of Writing Reports Etcetera, London, Clive Bingley, 1985.

Östman J.-O., «Persuasion as implicit anchoring. The case of collocations», Persuasion Across Genres: a Linguistic Approach, H. Halmari \& T. Virtanen (eds.), Amsterdam/Philadelphia, John Benjamins, 2005, pp. 183-212.

Partington A., «"Utterly content in each other's company" Semantic prosody and semantic preference" », International Fournal of Corpus Linguistics, $\mathrm{n}^{\circ}$ 9/1, 2004, pp. 131-156.

Rezaee Z. \& G. L. Porter, «Can the Annual Report Be Improved?», Review of Business, $\mathrm{n}^{\circ}$ 15/1, 1993, Summer-Fall, pp. 38-41.

Scott M., WordSmith Tools (Computer Software. Version 3.0), Oxford, Oxford University Press, 1998.

Sinclair J.M., Corpus, Concordance, Collocation, Oxford, Oxford University Press, 1991.

Sinclair J.M., Reading Concordances, London, Pearson Longman, 2003.

Sinclair J.M., Trust the Text. Language, Corpus and Discourse, London/New York, Routledge, 2004.

Stubbs M., Words and Phrases. Corpus Studies of Lexical Semantics, Oxford, Blackwell Publishers, 2001.

Thomas J., «Discourse in the Marketplace: The Making of Meaning in Annual Reports», The Fournal of Business Communication, $\mathrm{n}^{\circ}$ 34/1, 1997, January, pp. 4766.

Thompson G. \& Hunston S., «Evaluation: An introduction», Evaluation in text. Authorial Stance and the Construction of Discorse, S. Hunston \& G. Thompson (eds), Oxford, Oxford University Press, 2000, pp. 1-27.

Topalian A., «Executive perspective: 1 . Experienced reality. The development of corporate identity in the digital era », European Fournal of Marketing, $n^{\circ} 37 / 7-8$, 2003, pp. 1119-1132.

Tosun N., «Financial value and public relations», Corporate Communications: $A n$ International Fournal, $\mathrm{n}^{\circ}$ 9/3, 2004, pp. 202-208. 
Virtanen T. \& H. Halmari. «Persuasion across genres: Emerging perspectives», Persuasion Across Genres: a Linguistic Approach, H. Halmari \& T. Virtanen (eds.), Amsterdam/Philadelphia, John Benjamins, 2005, pp. 3-24.

Wainwright G., Report Writing: A Practical Guide to Effective Report Writing presented in Report Form, London, Management Update Ltd, 1984.

Watson M.L., Illusions of Trust: A Comparison of Corporate Annual Report executive Letters before and after SOX, A paper presented at the 8th International Public Relations Research Conference, Miami, FL, 2005, <http://www.instituteforpr.org/ipr_info/illusions_of_trust/>

White P.R.R., «Appraisal», Handbook of Pragmatics, J. Verschueren, J.-O. Östman, J. Blommaert, \& C. Bulcaen (eds.), Amsterdam/ Philadelphia, John Benjamins, 2002, pp. 1-27.

Yuthas K., Rogers R. \& J. F. Dillard. «Communicative Action and Corporate Annual Reports », Fournal of Business Ethics, $\mathrm{n}^{\circ} 41,2002$, pp. 141-157. 